Bangladesh J. Plant Taxon. 23(2): 119-131, 2016 (December)

(C) 2016 Bangladesh Association of Plant Taxonomists

\title{
LEAF MICROMORPHOLOGICAL FEATURES OF THE GENUS CORDIA L. (BORAGINACEAE) FROM EGYPT
}

\author{
WaFAA AMER, Rim HAMdy ${ }^{1}$ AND RiHAM MAHDY ${ }^{2}$ \\ Department of Botany \& Microbiology, Faculty of Science, Cairo University, Giza 12613, Egypt
}

Keywords: Cordia; Trichomes; Stomata; SEM; Egypt.

\begin{abstract}
Foliar epidermal characters of nine Cordia L. species found in Egypt are investigated. Glandular trichomes are observed in $C$. boissieri A. DC. and $C$. cylindristachya (Ruiz \& Pav.) Roem. \& Schult., while eglandular trichomes are predominant in all studied species. Different stomatal characters were examined including: shape, size, rims, stomatal level, aperture, cuticular deposition and wax ornamentation. The retrieved results showed a great variation among the studied species. The observed trichomes and stomata were used to construct two different taxonomic keys.
\end{abstract}

\section{Introduction}

Cordia L. is a large pantropical genus growing across the tropical and subtropical areas of America, Africa, Asia and Oceania (Al-Shehbaz, 1991) with 320 species of trees and shrubs. The genus is represented in the flora of Egypt by eight cultivated and one wild species.

Cordia myxa L. was recorded in ancient Egypt (Täckholm, 1961; Lucas, 1962; Darby et al., 1977 and Manniche, 1989). Its fruit was eaten fresh and used to make wine. It may also have been raised for the production of birdlime (Van der veen, 2011). Cordia sinensis Lam. is the only relict species in its wild form; traced in moist ground in oases and Gebel Elba (Täckholm, 1974; Boulos, 2009). It was also raised in the Israel-Palestine area and in the Arabian Peninsula (FeinbrunDothan, 1978).

Taxonomic treatments of Cordia L. have long been recognized by many workers (Johnston, 1930; Kazmi, 1970; Taroda and Gibbs, 1986; Al Nowaihi et al., 1987; Warfa, 1988; Verdcourt, 1991; El Mahi, 2012 and Mehrabian et al., 2014). Metcalfe and Chalk (1950) described the general anatomical properties of the family including some details of the genus Cordia and underlined the taxonomic value of trichomes and stomata and their involvement in systematics.

The micromorphological characters of the epidermal system (stomata, trichomes, epidermal wax deposits) have been received much attention in the recent past years. According to Rejdal (1991); monographs are considered incomplete without micromorphology of the epidermis. In the context, however, little attention was given to the genus Cordia. Recently Ventrella and Marinho (2008) studied foliar micromorphological of C. verbenacea DC from Brazil, Sharma et al. (2013) made identification of Cordia macleodii Hook. through stomatal index. As the earlier studies confirmed the importance of epidermal micromorphology in taxonomy (Stockey and Taylor 1978 a, b; Stace, 1984; Palmer and Gerbeth-Jones, 1986 and 1988; Yoon 1994; Hassan, 2004; Özcan, 2002). It reveals that foliar epidermal characters are important in taxonomic identification and species relationships in Cordia species. Despite the previous studies, genus Cordia L. received very little attention in Egypt. Therefore, the present study was undertaken to evaluate the features

${ }^{1}$ Corresponding author: Email: rimhamdy@yahoo.com

${ }^{2}$ Timber Trees and Forestry Department, Horticulture Research Institute, Agriculture Research Center, Giza, Egypt. 
of foliar trichomes and stomata in the genus Cordia L. growing in Egypt and to assess these characters for specific and interspecific delimitation. It was also aimed to construct two differential keys on the trichomes and stomatal characters to identify Cordia species from Egypt.

\section{Materials and Methods}

Nine species of Cordia used in this study are C. africana Lam., C. boissieri A. DC., C. crenata Delile, $C$. cylindristachya (Ruiz \& Pav.) Roem. \& Schult., $C$. dentata Poir., $C$. dichotoma G. Forst., C. myxa L., C. sebestena L. and C. sinensis Lam.

The localities of these species along with the voucher numbers are appended in Table 1. Fresh specimens collected and studied from different gardens as well as herbarium specimens deposited in Cairo University Herbarium (CAI), The Agriculture Research Centre, Flora of Phytotaxonomy Herbarium (CAIM) and Orman garden herbarium. Leaf material was examined by Scanning Electron Microscopy (SEM). Small pieces $\left(\right.$ c. $7 \mathrm{~mm}^{2}$ ) of dried mature leaf material were fixed to SEM stubs using double-sided adhesive tape, coated with gold in a sputter coat (SPI-Module), examined and photographed with a Jeol (JSM-5500 LV) using high vacuum mode at the Electron Microscope Unit, Regional Center of Mycology and Biotechnology at Azhar University, Cairo (Egypt).

Terminology of trichomes used are according to Al-Shammary and Gornell (1994); Bigazzi et al. (1999) and Taia (2006), while for stomata terminology Wilkinson (1983 \&1992) and El Hadidy (2004) were followed.

Table 1. List of species of Cordia L. along with voucher specimens used in the present study.

\begin{tabular}{|c|c|c|}
\hline No. & Species & Voucher specimens \\
\hline 1 & Cordia africana Lam. & $\begin{array}{l}\text { Aswan: Aswan botanic garden, 20. 2. 1996, H. Rafaeel } 29135 \text { (CAIM) } \\
\text { Giza: Mazhar botanic garden, Baragile, 24. 8. 2014, R. Mahdy s.n. (CAI) }\end{array}$ \\
\hline 2 & C. boissieri A. DC. & $\begin{array}{l}\text { Giza: Villa El Maghraby, 30. 4. 2004, T.Labib (Orman garden } \\
\text { herbarium) } \\
\text { Giza: Mazhar botanic garden, Baragile, 24. 8. 2014, R. Mahdy s.n. (CAI) }\end{array}$ \\
\hline 3 & C. crenata Delile & $\begin{array}{l}\text { Sudan: Jebel Dambobei, Karora, 25. 12. 1966, M. Kass, M. Mobarak\& } \\
\text { H. Omar } 1166 \text { (CAI) }\end{array}$ \\
\hline 4 & $\begin{array}{l}\text { C. cylindristachya (Ruiz \& } \\
\text { Pav.) Roem. \& Schult. }\end{array}$ & $\begin{array}{l}\text { Giza: Faculty of Agriculture, 5. 6. 1976, B. Diwan s.n. (Orman garden } \\
\text { Herbarium) }\end{array}$ \\
\hline 5 & C. dentata Poir. & $\begin{array}{l}\text { Giza: Orman garden, 5. 6. 1933, Khattab g1349 (CAIM) } \\
\text { Giza: Zoolgical garden, 22. 5. 2014, R. Mahdy s.n. (CAI) }\end{array}$ \\
\hline 6 & C. dichotoma Forst.f. & $\begin{array}{l}\text { Giza: Mazhar botanic garden, Baragile, 6. 5. 2011, M. El Said s.n. } \\
\text { Mazhar Herbarium } \\
\text { Giza: Mazhar botanic garden, Baragile, 24. 8. 2014, R. Mahdy s.n. (CAI) }\end{array}$ \\
\hline 7 & C. myxa L. & $\begin{array}{l}\text { Aswan: Aswan botanic garden, 12. 5. 1998, H. Rafaeel, } 29366 \text { (CAIM) } \\
\text { Giza: Zoolgical garden, 22. 5. 2014, R. Mahdy s.n. (CAI) }\end{array}$ \\
\hline 8 & C. sebestena $\mathrm{L}$. & $\begin{array}{l}\text { Giza: Orman garden, 28.7. 2007, Mostafa (Orman garden herbarium) } \\
\text { Giza: Mazhar botanic garden, Baragile, 24. 8. 2014, R. Mahdy s.n. (CAI) }\end{array}$ \\
\hline 9 & C. sinensis Lam. & $\begin{array}{l}\text { Giza: Orman garden, 10.7.1933, J. Shabetaig1354 (CAIM) } \\
\text { Giza: Zoolgical garden, 22. 5. 2014, R. Mahdy s.n. (CAI) }\end{array}$ \\
\hline
\end{tabular}




\section{Results and Discussion}

The genus Cordia offers different types of trichomes and stomata are summarized in Tables 2 and 3. Both glandular and eglandular trichomes are found in Cordia (Table 2). Glandular trichomes are observed only in C. boissieri (40-46 $\mu \mathrm{m}$, Fig.1A) and C. cylindristachya (33-38 $\mu \mathrm{m}$, Fig.1B); the earlier possess clavate head while the later posses globular head. Eglandular trichomes are evident in all species, however they vary in density and distribution; presence or absence of basal part (cell), with circular rim or pluricellular, shape of upper part (apical cell); with cylindrical, flattened or conical, their length and ornamentation.

The eglandular trichomes are simple unbranched; the majorities are medium-long sized upper part. Their length ranges from 108-833 $\mu \mathrm{m}$. These eglandular trichomes may be without basal part as in Cordia dichotoma (Fig. 1C) or with basal part. The basal part either in circular rim as in $C$. africana (Fig. 1D), in one pluricellular (C. myxa Fig. 2F and C. crenata Fig. 2A, B), or in more than one row of cells as shown in C. dentata (Fig. 2G). The eglandular trichomes in the studied taxa appeared cylindrical in C. africana (Fig. 1D), or flattened in C. dentata (Fig.1F), rarely conelike as in $C$. crenata (Fig. 2A). Trichome surface in the studied taxa appeared with variable surface namely: smooth (in C. dichotoma, Fig. 1C), granulate (in C. africana, Fig.1D), scaly (in $C$. dentata, Fig. 1F) or echinate (in C. boissieri, Fig. 1E).

Trichomes of the upper leaf surface of the studied taxa ranges from sparse (number of hairs / $1 \mathrm{~cm}^{2},<300$ ) in Cordia africana, C. myxa, C. dichotoma and C. dentata (Table 2). Cordia sinensis and $C$. sebestena possess moderate $(\geq 300-600)$. The dense $(\geq 600)$ appeared in $C$. boissieri, $C$. cylindristachya and $C$. crenata, while in the lower surface trichomes appeared dense in most of the studied species, sparse in $C$. dentata and very dense in C. boissieri (Table 2).

The following key was constructed on the basis of trichome features of the studied Cordia species as shown under SEM:

1 Eglandular and glandular present 2

- Only eglandular trichomes present 3

2 Glandular with clavate head C. boissieri

- Glandular with globular head C. cylindristachya

3 Basal part absent C. dichotoma

- Basal part present 4

4 Formed of circular rim $\quad$ C. africana

- $\quad$ Formed of pluricellular cells 5

5 Pluricellular base formed of more than two rows $\quad$ C. dentata

- Pluricellular base formed of one row 6

6 Distinct in cylindrical upper part C. crenata

- $\quad$ Not distinct in cylindrical upper part $\quad 7$

7 Scaly upper part C. myxa

- $\quad$ Granulate upper part 8

8 Granules coarse C. sinensis

- Granules fine C. sebestena

The epidermal and stomatal features of the studied Cordia species are summarized in Table 3. Stomata as seen under SEM showed high diversity in stomatal shape: round $(\mathrm{L}=1-1.2 \mathrm{~W})$ in $C$. africana, C. boissieri and C. cylindristachya (Fig. 3A, B \& Fig. 4C, D, E, F); narrowly elliptic 


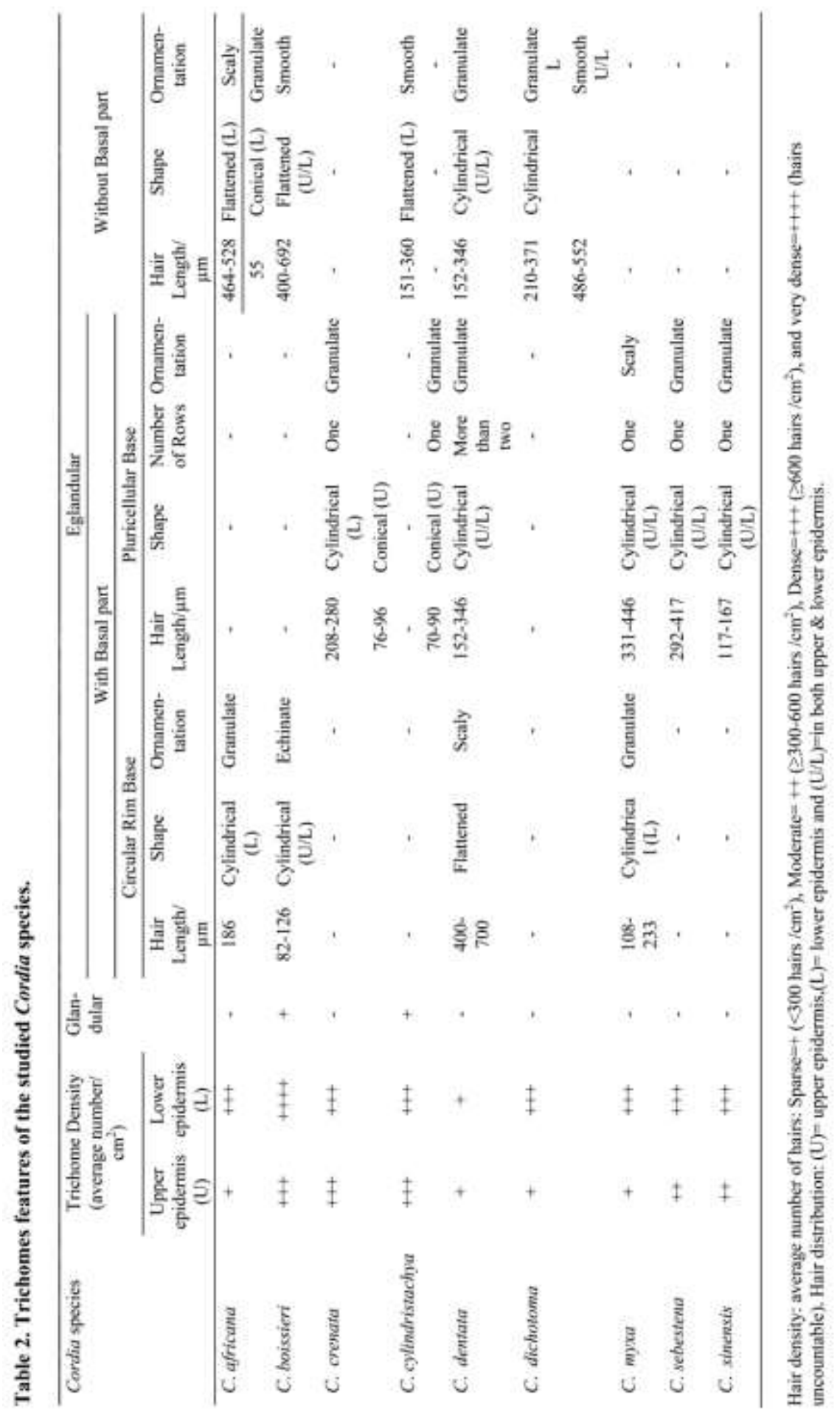




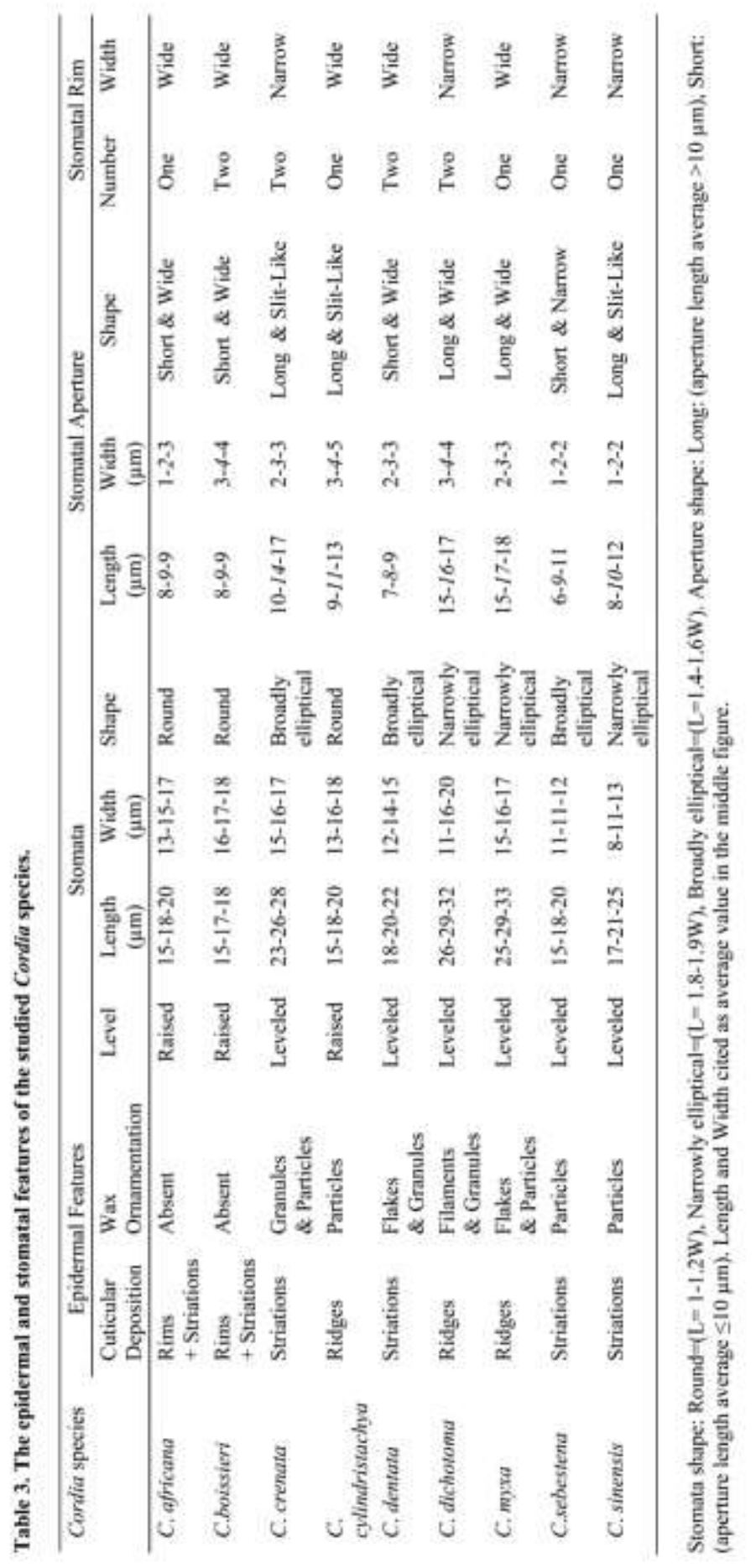


$(\mathrm{L}=1.8-1.9 \mathrm{~W}$ ) in $C$. sinensis, C. myxa and C. dichotoma (Fig. 3E, F \& Fig. 5A,B,C,D); while broadly elliptic ( $\mathrm{L}=1.4-1.6 \mathrm{~W})$ in $C$. sebestena, $C$. crenata and $C$. dentata (Fig. 3C,D, Fig. 4A, B \& Fig. 5E,F).

The stomatal size ranged from $15-33 \mu \mathrm{m}$ long and 8-20 $\mu \mathrm{m}$ wide. The largest in C. myxa and C. dichotoma while the smallest in $C$. sebestena. Some of the stomata show raised level as in $C$. africana, C. boissieri and C. cylindristachya, while other species are in the same level.
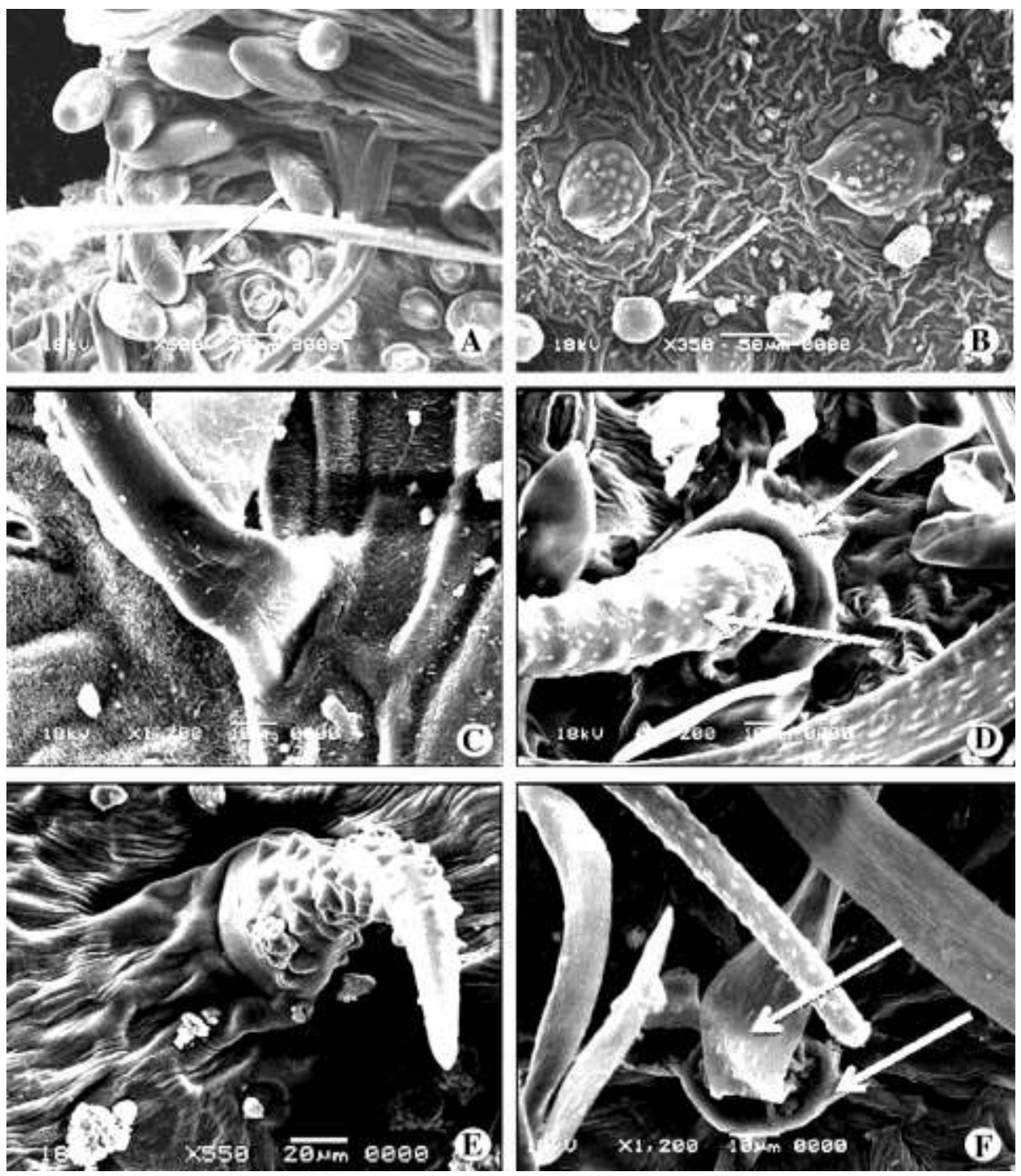

Fig. 1. SEM micrographs showing foliar trichomes in Cordia species. A-B Glandular trichomes: A. Clavate head of $C$. boissieri. and B. Globular head of C. cylindristachya. C-F Eglandular trichomes: C. Without basal part, cylindrical upper part of $C$. dichotoma, with smooth surface. D-E circular rim basal part: D. Cylindrical upper part of $C$. africana, with granulate surface, E. C. boissieri, with echinate surface. F. Flattened upper part of $C$. dentata with scaly surface. 

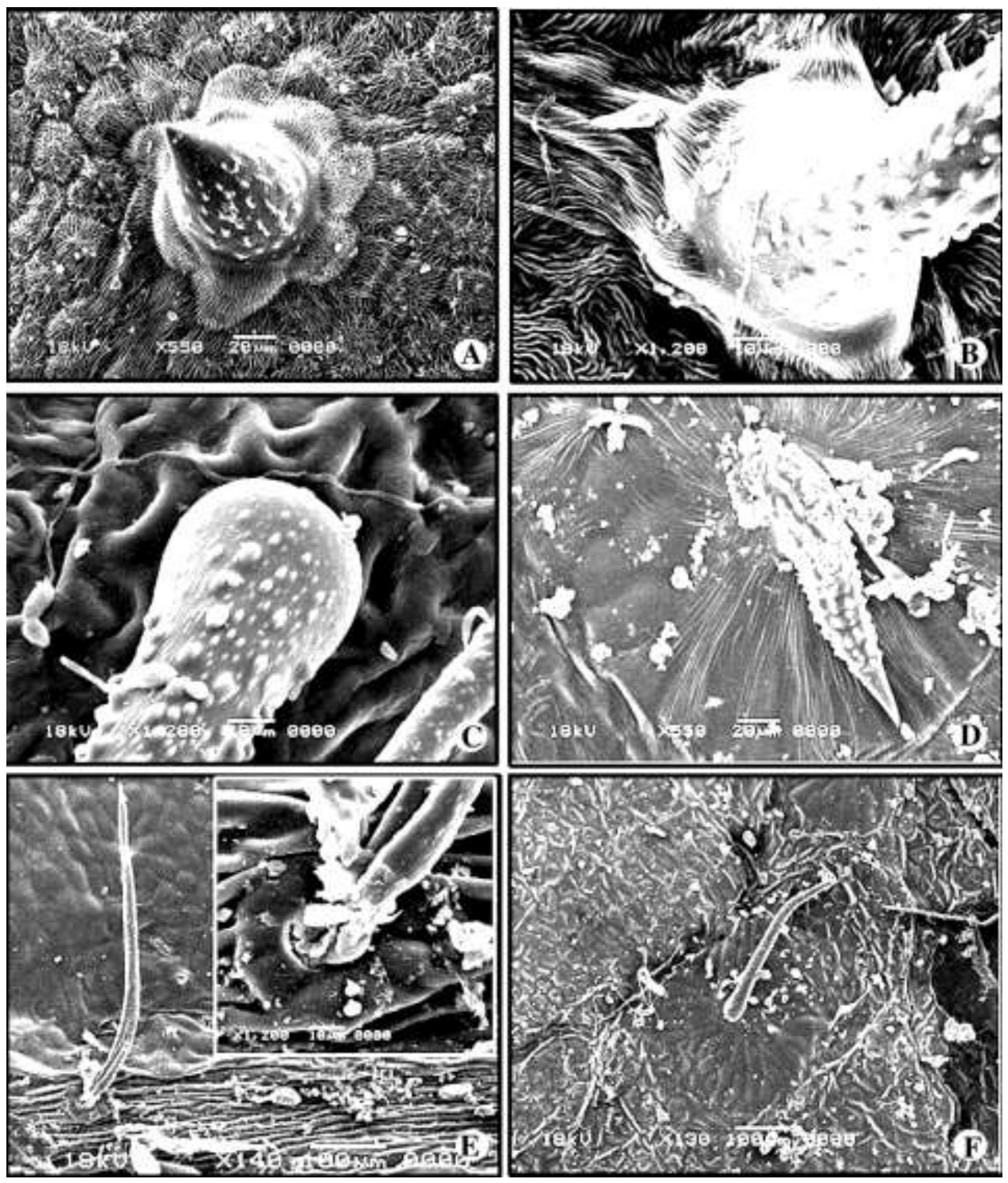

Fig. 2. SEM micrographs showing foliar trichomes in Cordia species. A-G eglandular trichomes with pluricellular basal part: A-F. In one row cells, A, B. C. crenata, A. conical upper part, B. cylindrical upper part, C. cylindrical upper part of $C$. sebestena, D. cylindrical upper part of $C$. sinensis, with granulate surface, E, F Cylindrical upper part of $C$. myxa, with scaly surface and G. pluricellular basal part in more than two rows of $C$. dentata.

The presence of stomatal rim is a diagnostic feature: single in $C$. africana (Fig. 3B), $C$. sebestena (Fig. 3D), C. sinensis (Fig. 3F), C. cylindristachya (Fig. 4F), C. myxa (Fig. 5B) and double in C. crenata (Fig. 4A), C. boissieri (Fig. 4D), C. dichotoma (Fig. 5D) and C. dentata (Fig. $5 \mathrm{~F})$. 

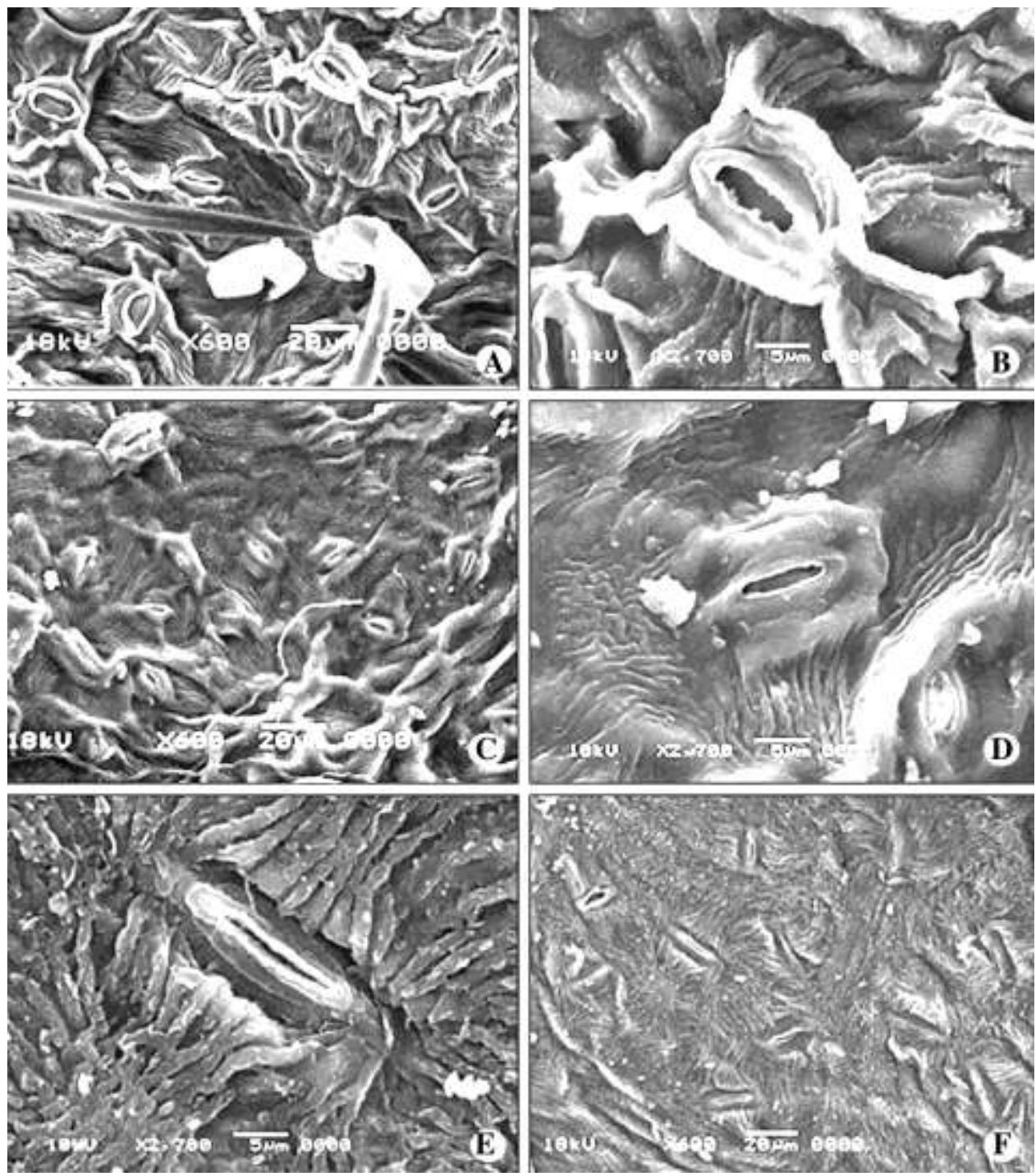

Fig. 3. SEM micrographs showing the stomatal pattern and magnified stomium in Cordia species. A, B: C. africana, C, D: C. sebestena, E, F: C. sinensis.

Stomatal opening (aperture) is variable among the studied taxa: long (average length $>10 \mu \mathrm{m}$ ) in $C$. dichotoma, C. myxa, C. crenata, C. cylindristachya and C. sinensis; short (average length $\leq 10 \mu \mathrm{m})$ in C. africana, C. boissieri, C. dentata and C. sebestena.

Cuticular deposits are observed in the form of striations or ridges; striations forming lateral wings perpendicular to the long axis of the subsidiary cells are observed in $C$. sinensis (Fig. 3E, F). Sometimes these striations radiating extend across more than one epidermal cell as in $C$. sebestena (Fig. 3C,D) and C. dentata (Fig. 5E,F). Striations distinguished C. crenata (Fig. 4A, B) and $C$. sinensis (Fig. 3E, F) from the rest of the studied species. However in C. africana the stomata are enclosed by undulated rim. Also striations extend across more than one epidermal 
cells (Fig. 3A, B). These striations sometimes form short lateral wings perpendicular to the long axis of the subsidiary cells in C. boissieri (Fig. 4C, D). Cordia cylindristachya can be distinguished from the other studied species with the presence of stomata located on epidermal ridges forming lateral wings perpendicular to the long axis of the stomatal cells (Fig. 4E, F). These ridges are crescentic and mostly parallel (occasionally perpendicular) to the long axis of the subsidiary cells as observed in C. myxa (Fig. 5A, B) while appears crescentic perpendicular to the long axis of the subsidiary cells in C. dichotoma (Fig. 5 C, D).

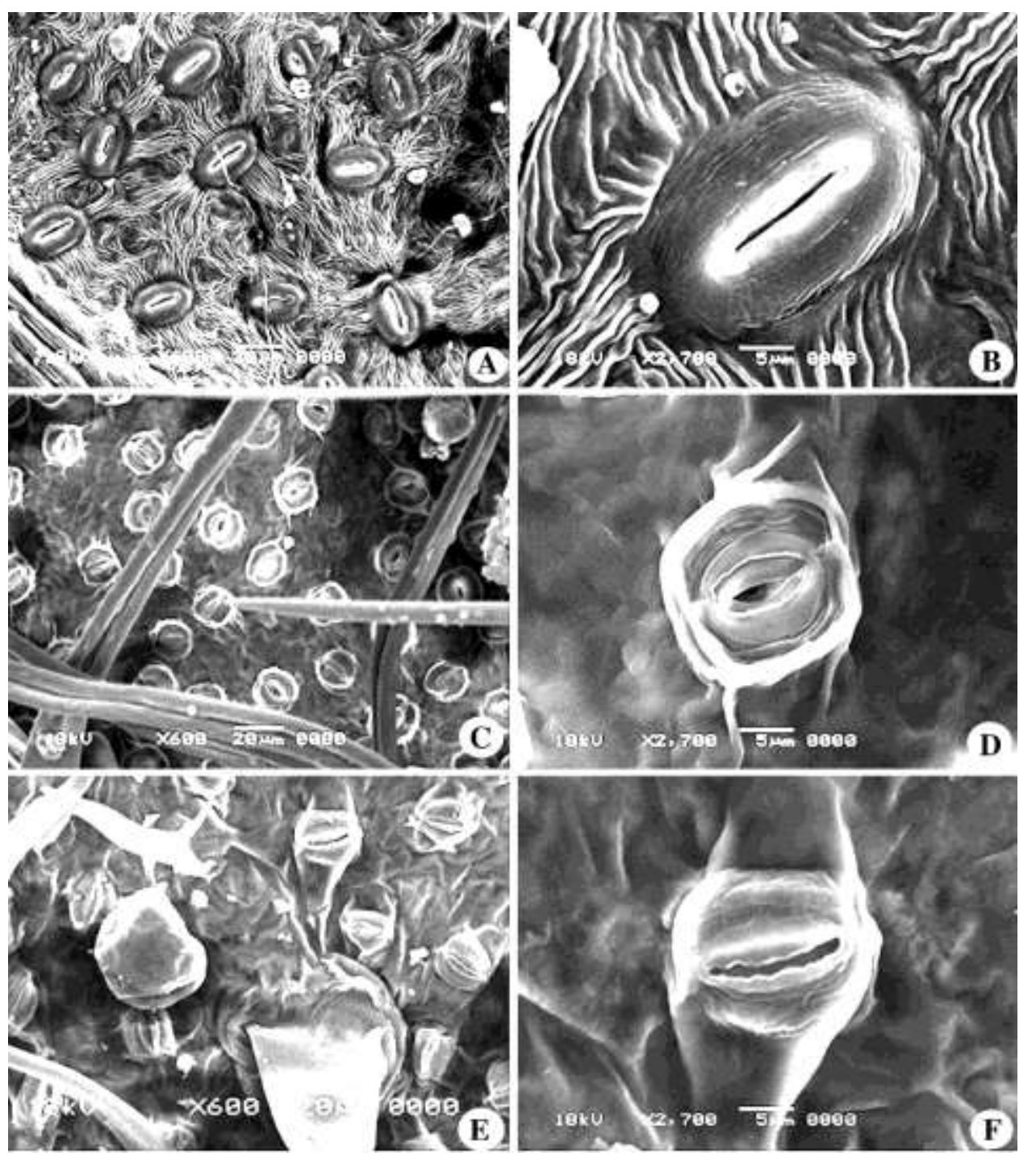

Fig. 4. SEM micrographs showing the stomatal pattern and magnified stomium in Cordia species. A, B: $C$. crenata, C, D: C. boissieri, E, F: C. cylindristachya. 

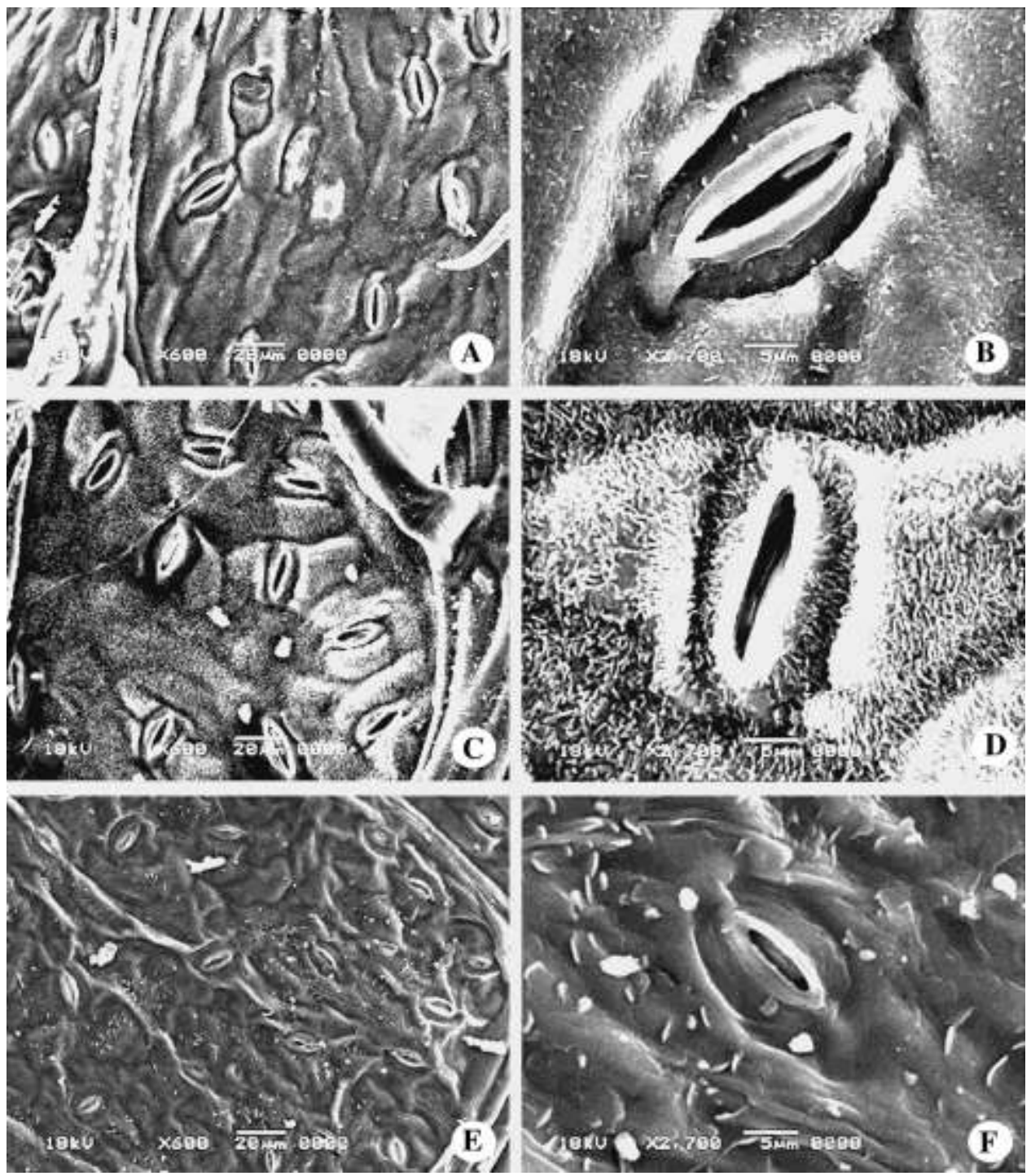

Fig. 5. SEM micrographs showing the stomatal pattern and magnified stomium in Cordia species. A, B: $C$. myxa, C, D: C. dichotoma, E, F: C. dentata.

The SEM of the epidermal system showed the presence of special wax structures (filaments, particles, flakes and granules, Table 3) in the studied taxa. Particles are observed in $C$. cylindristachya, C. sebestena and C. sinensis. These particles mixed with flakes in C. myxa (Fig. 5 B) or mixed with granules in $C$. crenata (Fig. 4B), while flakes and granules are observed in $C$. dentata (Fig. 5F) filaments and granules in C. dichotoma (Fig. 5D). The following key was constructed on the basis of the stomatal and epidermal features of the studied taxa as shown under SEM. 
1 Obvious epidermal striations 2

- Obscure epidermal striations 5

2 Stomata with cuticular rim

C. africana

- Stomata without cuticular rim

3

3 Cuticular deposition with unconspicuous striations extending across more than one epidermal cell

C. sebestena

Cuticular deposition with conspicuous striations, not extending across more than one epidermal cell

4

4 Striations only perpendicular to the long axis of the subsidiary cells

C. sinensis

- Striations radiating all over the stomata

C. crenata

5 Stomata round

- Stomata elliptic

6 Stomata on ridge without stomatal rim

C. cylindristachya

- Stomata not on ridge, with stomatal rim

C. boissieri

7 Stomata broadly elliptic

C. dentata

- Stomata narrowly elliptic

8

8 Epidermis with dense waxy filaments

C. dichotoma

- Epidermis not so

C. myxa

In our study Cordia myxa and C. dichotoma have been found closely related (Verdcourt, 1991) as attested by the following shared characters: lamina broadly ovate to suborbicular, inflorescence dichotomous branching, flowers salverform and white, stigma flattened and subfoliaceous with irregular or erose-denticulate margin, fruit yellowish orange. However the epidermal features do not support a close association between them, using micromorphological characters during this study to distinguish both species; the eglandular trichomes without basal part is observed in C. dichotoma (Fig. 1C) while basal part is pluricellular in C. myxa (Fig. 2F). Also wax ornamentation is formed of particles in addition to flakes in C. myxa (Fig. 5A, B) and filaments and granules in C. dichotoma (Fig. 5C, D).

Stomata in Cordia are usually confined to lower side (Metcalfe and Chalk, 1950). The results outlined in Table (3), indicate that stomatal rim and wax ornamentation is found to be significant characters; stomatal rim was double in C. boissieri, C. crenata, C. dentata and C. dichotoma and single in C. africana, C. cylindristachya, C. myxa, C. sebestena and C. sinensis (Figs.3, 4,5). Wax ornamentation is formed of particles and granules in C. crenata (Fig. 4A, B), C. myxa with particles and flakes (Fig. 5A, B), C. dichotoma with filament and granules (Fig. 5C, D) while $C$. dentata characterized flakes and granules (Fig. 5E, F).These results are in accordance with that of Akcin et al., (2013), who claimed that, the stomatal rims and wax ornamentations are important characters for delimiting fourteen species of Onosma L.

Cordia cylindristachya was distinguished from other species, by stomata located on epidermal ridge (Fig. 4E, F) which was confirmed earlier by Metcalfe and Chalk (1950) on some Cordia species.

Finally, we conclude that the micromorphological characters of Cordia species such as presence of eglandular and glandular trichomes, presence or absence, shape and ornamentation of 
basal trichome part, stomatal rim and wax ornamentation possess diagnostic taxonomic value which can delimit Cordia species.

\section{References}

Akçin Ö.E., Şenel G. and Akçin, Y. 2013. Leaf epidermis morphology of some Onosma (Boraginaceae) species from Turkey. Turk. J. Bot. 37: 55-640.

Al-Nowaihi, A.S., Khalifa, S.F. and Hamed, K. 1987. A contribution to the taxonomy of Boraginaceae. Phytologia 62: 107-125.

Al-Shammary, K.I.A., and Gornall, R.J. 1994. Trichome anatomy of the Saxifragaceaes. 1. from the southern hemisphere. Bot. J. Linn. Soc. 114: 99-131.

Al-Shehbaz, I.A. 1991. The genera of Boraginaceae in the Southeastern United States. J. Arnold Arb. Suppl. 1: $1-169$.

Bigazzi, M., Selvi, F. and Fiorini, G. 1999. A reappraisal of the generic status of Gastrocotyle, Hormuzakia and Phyllocara (Boraginaceae) in the light of micromorphological and karyological evidence. Edinb. J. Bot. 56(2): 229-251.

Boulos, L. 2009. Flora of Egypt Checklist, El Hadara Publishing, Cairo, Egypt, 410p.

Darby, W., Ghallioungui, P., Griffith, L. 1977. Food: The gift of Osiris. Vol. 1 \& 2, Academic press, London, New York, San Francisco.

Dasti, A.A., Bokhari, T.Z., Malik, S.A. and Akhtar, R. 2003. Epidermal morphology in some members of family Boraginaceae in Baluchistan. Asian J. Plant Sci. 2(1): 42-47.

El Hadidy, A.M.H. 2004.Morphological studies on fruits and seeds of the genus Lotus L. in Egypt, Proceedings of First International Conference on Strategy of Egyptian Herbaria March 9-11, 2004; Giza, Egypt.129-159.

El Mahi, H.O.A. 2012. Taxonomic revision of the family Boraginaceae in Sudan. Ph.D. Thesis, Botany Department, Faculty of Science, University of El Khartoum.

Feinbrun-Dothan, N. 1978. Boraginaceae, Flora Palaestina, Vol. 3, Israel Academy of Science and Humanities, Jerusalem.

Hassan, S.A. 2004. Stomatal diversity in certain species of Apocynaceae and its bearing on taxa delimitation. Taeckholmia 24 (1): 21-31.

Johnston, I.M. 1930. Studies in Boraginaceae. VIII. Contrib. Gray Herb. Harvard Uni. 92: 1-89.

Johnston, I.M. 1935a. Studies in Boraginaceae. X. The Boraginaceae of Northeastern South America. J. Arnold Arb. 16: 1-64.

Johnston, I.M. 1935b. 3. New or otherwise noteworthy species. J. Arnold Arb. 16: 173-181.

Johnston, I.M. 1937. Studies in the Boraginaceae. XII - 1.Trigonotis in Southwestern China. 2. Novelties and Critical Notes. J. Arnold Arb. 18: 10-13.

Johnston, I.M. 1940. Studies in Boraginaceae. XV. Notes on some Mexican and Central American species of Cordia. J. Arnold Arb. 21: 336-355.

Johnston, I.M. 1948. Studies in the Boraginaceae. XVI - Species chiefly from Mexico and Western United States. J. Arnold Arb. 29: 227-240.

Johnston, I.M. 1949a. Studies in the Boraginaceae. XVII. A. Cordia section Varronia in Mexico and Central America. J. Arnold Arb. 30: 85-106.

Johnston, I.M. 1949b. Studies in the Boraginaceae. XVII. Boraginsaceae of the Southern West Indies. J. Arnold Arb. 30(2): 111-138.

Johnston, I.M. 1951. Studies in the Boraginaceae. XX. Representatives of three subfamilies in Eastern Asia. J. Arnold Arb. 32(2): 1-26.

Johnston, I.M. 1956. Studies in the Boraginaceae. XXVIII. New or otherwise interesting species from America and Asia. J. Arnold Arb. 37: 288-306. 
Kazmi, S.M.A. 1970. A revision of the Boraginaceae of West Pakistan and Kashmir. J. Arnold Arb. 51: 133184.

Lucas, A. 1962. Ancient Egyptian materials and industries. Fourth edition, Revised by J.R. Harris, E. Arnold, London.

Manniche, L. 1989. An ancient Egyptian herbal, British Museum Publications, Austin.

Mehrabian, A.R., Sheidai, M. and Mozaffarian, V. 2014. Micromorphology of leaf trichomes in Onosma (Boraginaceae) and their systematic relevance in Iran. Phytol. Balcan. 20 (1): 33- 48.

Metcalfe, C.R. and Chalk, L. 1950. Anatomy of Dicotyledons, Second edition, Clarendon Press, Oxford.

Özcan, T. 2002. SEM observation on petals and fruits of some Turkish endemic Buplerum L. (Umbelliferae) species. Bot. J. Linn. Soc. 138 (4): 441-449.

Palmer, P.G. and Gerbeth-Jones, S. 1986.A scanning electron microscope survey of the epidermis of East African grasses IV. Smithson. Contr. Bot. 49: 1-120.

Palmer, P.G. and Gerbeth-Jones, S. 1988. A scanning electron microscope survey of the epidermis of East African grasses V and West African supplement. Smithson. Contr. Bot. 67: 1-153.

Rejdali, moh.F.L.S. 1991. Leaf micromorphology and taxonomy of North African species of Sideritis L. (Lamiaceae). Bot. J. Linn. Soc. 107(1): 67-77.

Sharma, A., Acharya, R.N., Shukla, V.J., Harisha, C.R. and Gupta, S.K. 2013. Identification of Cordia macleodii Hook. through DNA finger printing and stomatal index. Universal Journal of Pharmacy - UJP 2(3): 98-101.

Stace, C.A. 1984. The taxonomic importance of the leaf surface. In: Heywood, V.H., Moore, D.F. (Eds), Current Concepts of Plant Taxonomy. Academic Press, London, pp. 31-39.

Stockey, R.A. and Taylor, T.N. 1978a. Scanning electron microscopy of epidermal patterns and cuticular structure in genus Araucaria. Scan. Electron Microsc. 2: 223-228.

Stockey, R.A. and Taylor, T.N. 1978b. Cuticular features and epidermal patterns in the genus Araucaria de Jussieu. Bot. Gaz. 139: 490-498.

Täckholm, V. 1961. Botanical identification of the plants found at the Monastery of Phoebammon. In: Bachatly, C. (Ed.) La Monastère de Phoebammon dans la Thébaïde. Cairo.

Täckholm, V. 1974. Student's flora of Egypt, second edition, Cairo University, Beirut.

Taia, W.K. 2006. Family Boraginaceae: Hair variations and their significance in the systematic of the Genera. Asian J. Plant Sci. 5(3): 441-454.

Taroda, N.1984. Taxonomic studies on Brazilian species of Cordia L. (Boraginaceae). Ph.D. Thesis, University of Saint Andrews, Saint Andrews. pp. 1-232.

Taroda, N. and Gibbs, P. 1986. Studies of the genus Cordia L. (Boraginaceae) in Brazil. 1. A new infrageneric classification and conspectus. Rev. Bras. Bot. 9: 31-42.

Van der Veen, M. 2011. Consumption, trade and innovation. Journal of African Archaeology Monograph series (JAAMs) 6: 1-313.

Ventrella, M.C. and Marinho, C.R. 2008.Morphology and histochemistry of glandular trichomes of Cordia verbenacea DC. (Boraginaceae) leaves. Rev. Bras. Bot. 31(3): 457-467.

Verdcourt, B. 1991. Boraginaceae. In: Polhili, R.M. (Ed.), Flora of Tropical East Africa. A. A. Balkema, Rotterdam, Brookfield, Netherlands, $124 \mathrm{p}$.

Warfa, A.M. 1988. Cordia (Boraginaceae) in NE Tropical Africa and Tropical Arabia. Acta Universitatis Upsaliensis - Comprehensive Summaries of Uppsala Dissertations from the Faculty of Science 174: 180.

Wilkinson, H.P. 1983. Leaf anatomy of Gluta (L.) Ding Hou (Anacardiaceae). Bot. J. Linn. Soc. 86: 375-403. Wilkinson, H.P. 1992. Leaf anatomy of the Pittosporaceae R. Br. Bot. J. Linn. Soc. 110: 1-59.

Yoon, C.Y. 1994. A taxonomic study on the genus Angelica L. in Korea and adjacent region. Ph.D. Thesis, Korea University, Korea. 